Jurnal DIALOGIKA Manajemen dan Administrasi

Homepage: https://ejurnal.unma.ac.id/index.php/dialogika

Vol. 1 No. 1, Oktober 2019, halaman: 27 37

E-ISSN: 2720-9865, P-ISSN: 2716-3563

DOI : https://doi.org/10.31949/dialogika.v1i1.2158

\title{
PENGUATAN KAPASITAS SUMBER DAYA MANUSIA BIDANG ADMINISTRASI DALAM MENINGKATKAN PELAYANAN PUBLIK
}

\author{
Lalan Soeherlan S \\ Magister Ilmu Administrasi, Pascasarjana Universitas Majalengka, Majalengka, Jawa Barat, Indonesia \\ e-mail korespondensi : lalansoeherlans@gmail.com
}

Disubmit Agustus 2019 , Diterima September 2019, Diterbitkan Oktober 2019

Submitted August 2019, Accepted September 2019, Published October 2019

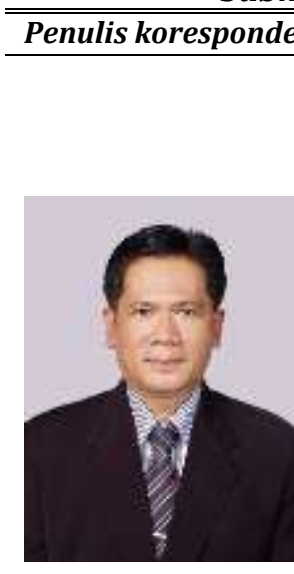

\begin{abstract}
Strengthening the capacity of human resources administration is an absolute necessity in the effort to improve public services. There are three things that underlie capacity strengthening, namely: the demands of policy on public services; Community demands on public services are growing in accordance with increasing public awareness; And demands of the Revolution 4.0 industry discourse. Aims to prepare human resources administration in order to be able to work professionally in improving public services. The method used is the library research is qualitative interpretative. Results showed that strengthening capacity needs to pay attention to three things, namely the level of development of individual capacity with the target of knowledge, skills, competence and ethics; Conducted through education and training with a five-stage process, namely: 1) involving stakeholders; 2) analyzing capacity and needs; 3) Formulating the response; 4) Apply the response; and 5) evaluation. The education and training process should also pay attention to the capacity aspects, 1) Performance capacity; 2) Personal capacity; 3) Workload capacity; 4) Supervisory capacity; 5) Facility capacity; 6) Support service capacity; 7) Systems capacity; 8) Structural capacity; and 9) Role capacity.
\end{abstract}

\begin{abstract}
Keywords: Capacity; Human resources; Administration; Public services.
Abstrak

Penguatan kapasita Sumber Daya Manusia bidang administrasi merupakan kebutuhan mutlak dalam upaya meningkatkan pelayanan publik. Terdapat tiga hal yang mendasari penguatan kapasitas, yaitu : Tuntutan kebijakan tentang pelayanan publik; Tuntutan masyarakat tentang pelayanan publik yang semakin berkembang sesuai dengan peningkatan kesadaran masyarakat; dan Tuntutan wacana revolusi industry 4.0. Bertujuan untuk mempersiapkan SDM bidang administrasi agar mampu bekerja secara professional dalam meningkatkan pelayanan publik. Metode yang digunakan yaitu library research bersifat kualitative-interpretative. Hasil menunjukan bahwa penguatan kapasitas perlu memperhatikan tiga hal, yakni tingkat pengembangan kapasitas individu dengan sasaran pengetahuan, keterampilan, kompetensi dan etika; Dilakukan melalui pendidikan dan pelatihan dengan proses lima tahapan, yaitu : 1) Mengikutsertakan stakeholders; 2) Menganalisis kapasitas dan kebutuhan; 3) Merumuskan respon; 4) Menerapkan respon; dan 5) Evaluasi. Proses pendidikan dan pelatihan perlu juga memperhatikan aspek kapasitas, 1) Performance capacity; 2) Personal capacity; 3) Workload capacity; 4) Supervisory capacity; 5) Facility capacity; 6) Support service capacity; 7) Systems capacity; 8) Structural capacity; dan 9) Role capacity.
\end{abstract}

Jurnal DIALOGIKA diterbitkan oleh Program Pascasarjana Administrasi Publik Universitas Majalengka

Kata kunci: Kapasitas; Sumber Daya Manusia; Administrasi; Pelayanan Publik.

\section{PENDAHULUAN}

Perkembangan ilmu pengetahuan dan teknologi terus melaju melampaui bidang- bidang lain dan mampu menembus berbagai aspek kehidupan manusia. Kemajuan bidang information and communicatin Technology 
(ICT) tampil lebih dominan, bahkan hampir tidak ada satu pun bidang kehidupan yang tak terjamah teknologi tersebut, termasuk bidang administrasi yang erat kaitannya dengan pelayanan publik.

Dengan munculnya istilah revolusi industri 4.0, di mana teknologi menjadi dasar aktivitas manusia, berbagai hal seakan tak memiliki batas (borderless) ditopang juga dengan bantuan komputer yang mampu menghimpun data tanpa batas (unlimited) karena dipadukan dengan perkembangan internet dan teknologi digital yang semakin mudah didapat. Hal tersebut memungkinkan terjadinya aktivitas dan konektivitas manusia dengan mesin yang semakin akrab. (Rohida,2018). Masa diberlakukannya sistem komputerais disadari atau tidak telah menjadikan manusia yang memiliki sikap individual, karena terlalu fokus kepada mesin (komputer). Seperti yang dikemukakan seorang ahli bahwa salah satu indikator yang dapat dikenali dengan mudah adalah munculnya perubahan sikap dan perilaku individual (Simangunsong, 2011). Dengan kata lain, era revolusi industri pun secara tidak disadari telah mereduksi berbagai aktivitas manusia karena tergantikan oleh mesin, robot, atau program komputer, padahal masalah sumber daya manusia merupakan salah satu unsur penting dalam organisasi. Sumber daya manusia harus mampu berperan menentukan arah organisasi, bukan sebaliknya. Maka, diperlukan upaya penguatan kapasitas sumber daya manusia yang benar-benar humanis, menjadikan manusia yang terampil menggunakan teknologi tetapi tidak menjadi robot.

Namun demikian, proses digitalisasi yang dipadukan dengan jasa layanan internet mendorong berbagai aktivitas manusia yang serba on-line, bahkan revolusi industri 4.0 merupakan suatu keniscayaan, dalam arti sulit untuk dihindari. Selain itu, revolusi industri 4.0 telah menunjukkan dampak nyata terhadap kehidupan manusia pada berbagai aspek di seluruh dunia. Semua proses dilakukan dengan sistem otomatisasi sebagai dampak dari perkembangan teknologi internet yang semakin pesat. Bahkan bukan hanya menghubungkan manusia di seluruh dunia, tetapi juga menjadi basis andalan bagi proses transaksi perdagangan dan transportasi secara online (Hamdan, 2018).

Salah satu alasan tentang pentingnya revolusi industri 4.0 didukung data yang menyatakan bahwa lebih dari 55\% organisasi beranggapan bahwa digital talent gap semakin menganga (LinkedIn, 2017). Oleh karena itu, Zimmerman dalam Pannen (2018) menyatakan bahwa di era 4.0 ke depan sekitar $75 \%$ pekerjaan akan melibatkan kemampuan sains, teknologi, teknik dan matematika, dan bahkan internet of things. Perubahan yang terjadi akan sangat cepat, karena setiap komponen yang terlibat akan merasa dituntut bergerak cepat. Jika tidak cepat akan tertinggal sehingga proses revolusi semakin tak terhindarkan. Revolusi yang dimaksud berbasis Cyber Physical System yang merupakan gabungan antara domain digital, fisik, dan biologi (Klaus Schwab, 2017). Maka untuk dapat mengimbangi perubahan tersebut, sumber daya manusia semakin penting untuk diperkuat kapasitasnya agar memiliki kecakapan sosial (social skill), termasuk SDM yang bergerak di bidang administrasi pelayanan publik. Salah satu kapasitas yang harus ditingkatkan adalah keterampilan, seperti yang dikemukakan Kamariah (2012) bahwa sedikitnya terdapat tiga pengukuran kapasitas Sumber Daya Manusia, yaitu: a) Kapasitas pengetahuan; b) Kapasitas keterampilan; dan c) Perilaku dan etika kerja. Secara umum dapat dikatakan bahwa kapasitas sumber daya manusia adalah kompetensi individu di dalam suatu kelembagaan yang mampu melaksanakan tugas, fungsi, dan kewenangannya dalam mencapai tujuan secara efektif dan efisien (Amin at.all, 2016). Secara lebih spesifik, kapasitas harus dilihat sebagai kemampuan untuk mencapai kinerja, yaitu menghasilkan keluaran-keluaran (ouput) dan hasil-hasil (outcomes) yang diinginkan lembaga (organisasi). Penguatan kapasitas SDM di era revolusi industri 4.0 akan sangat bermanfaat, karena SDM yang bekerja sesuai kapasitasnya dapat menghemat waktu dalam pelaksanaan kerja dan pembuatan laporan. (Sonia, 2016).

Berkenaan dengan istilah kapasitas, Nasution (2011:1), mengemukakan bahwa "Kapasitas atau kemampuan individu adalah kesanggupan atau kecakapan yang berarti 
bahwa seseorang yang memiliki kecakapan atau kesanggupan untuk mengerjakan sesuatu yang diwujudkan melalui tindakannya untuk meningkatkan produktivitas kerja". Oleh karena itu, jika dikaitkan dengan istilah penguatan atau pengembangan, kapasitas adalah upaya meningkatkan kemampuan individu agar pegawai memiliki kompetensi yang lebih baik agar lebih produktif dalam mencapai tujuan yang telah ditentukan oleh lembaga (organisasi) sebelumnya.

Saat ini, di era revolusi industri 4.0 kapasitas pegawai difokuskan kepada keterampilan atau penguasaan terhadap penggunaan teknologi informasi dan komunikasi berbasis data yang dipadukan dengan jaringan internet. Artinya, penguatan kapasitas SDM dalam penelitian ini lebih difokuskan pada keterampilan penggunaan ICT. Untuk menghadapi perubahan yang lebih cepat di masa yang akan datang, pengembangan kapasitas SDM sangat urgent untuk terus ditingkatkan dengan maksud membangun kompetensi manusia sebagai pengelola administrasi dalam pelayanan publik. (Basnawi, 2017). Definisi yang lebih teknis tentang revolusi industri 4.0 dikemukakan Kagermann dkk. (2013), bahwa Industri 4.0 merupakan perpaduan atau integrasi antara Cyber Physical System (CPS) dengan Internet of Things and Services (IoT dan IoS) ke dalam proses industri meliputi manufaktur, logistik, dan proses lainnya.

Adapun yang dimaksud dengan SDM adalah sumber daya manusia yang merupakan salah satu unsur dalam organisasi yang berperan penting dalam menjamin keberlangsungan dan aktivitas suatu organisasi. Sutrisno (2010:4), mengemukakan bahwa sumber daya manusia dapat diartikan sebagai sumber kekuatan organisasi yang berasal dari manusia yang dapat didayagunakan oleh organisasi". Dari teori tersebut dapat dijelaskan bahwa manusia memiliki potensi yang perlu diberdayakan dan ditingkatkan kualitasnya agar dapat menjadikan organisasi menjadi lebih baik dan memiliki daya saing. Dalam pembahasan ini, SDM yang dimaksud adalah sumber daya manusia yang berkerja di bidang administrasi publik di lingkungan pemerintah Daerah.
Urgensi penguatan kapasitas SDM pemerintah daerah dalam meningkatkan kualitas pelayanan publik saat ini, didasari tiga hal. Pertama, memenuhi tuntutan kebijakan pemeritah pusat dan daerah, berkaitan dengan amanat Undang-undang Republik Indonesia Nomor 25 Tahun 2009 tentang Pelayanan Publik, khususnya amanat yang tertera pada Pasal 10 ayat (1) dan (2) yang menyatakan bahwa: (1)Penyelenggara berkewajiban melak-sanakan evaluasi terhadap kinerja pelaksana di lingkungan organisasi secara berkala dan berkelanjutan; dan (2) Berdasarkan hasil evaluasi sebagaimana dimaksud pada ayat (1), penyelenggara berkewajiban melakukan upaya peningkatan kapasitas pelaksana. Kedua, pemenuhan tuntutan empiris bahwa peningkatan kualitas pelayanan publik terus berkembang seiring dengan semakin meningkatnya kesadaran masyarakat. Bahwa warga Negara memiliki hak untuk dilayani, sedangkan kewajiban pemerintah adalah untuk memberikan pelayanan yang terbaik kepada masyarakat (Pratama, 2015); Ketiga, berkenaan dengan dampak dari implementasi revolusi industri 4.0 aspek sumber daya manusia, yang mutlak diperlukan usaha untuk mempersiapkannya dalam bentuk mentransformasi SDM agar siap menghadapi perubahan akibat Industri 4.0. (Prasetyo, 2018).

Ketiga alasan tersebut merupakan titik tolak pemikiran guna mempersiapkan SDM bidang Administrasi publik agar pada saatnya nanti mampu memberikan pelayanan publik yang berkualitas sesuai tuntutan perubahan. Keterampilanm SDM bidang administrasi dalam penerapan teknologi berbasis digital, diyakini akan mampu memberikan pelayanan secara daring. Mengingat di dunia kerja yang sebenarnya, pelayanan administrasi publik saat ini sudah mulai menggunakan sistem online. Misalnya pelayanan e-KTP, proses pendaftaran CPNS, pelaporan SPPT, laporan kerja bulanan PNS. Di bidang pendidikan, semua aktivitas akademik dan pengelolaan pendidikan dilaporkan secara daring, demikian juga halnya di dunia bisnis dan $e$ commerce sudah lama menjadi bagian dari sistem tersebut.

Adapun yang dimaksud dengan pelayanan publik adalah suatu kegiatan atau urutan kegiatan yang terjadi dalam interaksi 
langsung antar seseorang dengan orang lain atau orang dengan mesin secara fisik, dan memenuhi kebutuhan masyarakat. Menurut UU RI Nomor 25 tahun 2009 tentang Pelayanan Publik, pada Bab I, Pasal 1, ayat (1) dikemukakan "Pelayanan publik adalah kegiatan atau rangkaian kegiatan dalam rangka pemenuhan kebutuhan pelayanan sesuai dengan peraturan perundangundangan bagi setiap warga negara dan penduduk atas barang, jasa, dan/atau pelayanan administratif yang disediakan oleh penyelenggara pelayanan publik".

Dilihat dari sudut pandang manajemen, banyak cara yang dapat digunakan untuk meningkatkan pelayanan publik. Antara lain dengan perencanaan yang akurat dalam bentuk Rencana Strategis yang logis, meningkatkan intensitas pengawasan, memantapkan pembinaan di berbagai tingkatan manajemen. (Rinaldi, 2012) Namun alternatif yang dipilih dalam pembahasan ini lebih menekankan pada penguatan kapasitas individu dalam mempersiapkan sumber daya manusia menyongsong implementasi revolusi industri 4.0. Tujuan dari pembahasan topik ini adalah untuk memberikan gambaran terpola tentang bagaimana upaya yang dapat dilakukan pemerintah daerah dalam memperkuat kapasitas sumber daya manusia bidang administrasi dalam upaya meningkatkan pelayanan publik. Sehingga, pembahasan ini diharapkan dapat memberikan manfaat bagi para pemangku kebijakan strategis untuk dijadikan bahan pertimbangan dalam mengambil keputusan berkenaan dengan upaya meningkatkan kompetensi dan kapasitas sumber daya manusia yang pada gilirannya akan berdampak kepada kualitas pelayanan publik.

\section{METODE PENELITIAN}

Penyajian gagasan dalam artikel ini menggunakan metode penelitian dengan pendekatan library research bersifat kualitative-interpretative. Data-data yang dibutuhkan dikumpulkan melalui telaah literatur, baik dari buku-buku, makalah ilmiah, laporan hasil penelitian, makalah yang disajikan pada pertemuan ilmiah para pakar maupun lembaga terkait. Data yang diperoleh dianalisis dengan pendekatan deskriptif interpretatif, dengan cara membandingkan data dengan teori, lalu diinterpretasikan sesuai tujuan dan sifat penelitian untuk disimpulan. Dilihat dari aspek kejelasan variabel, pembahasan terdiri atas dua variabel, yakni variabel bebas (penguatan kapasitas SDM), dan variabel terikat (pelayanan publik). Dengan demikian, arah interpretasi data difokuskan kepada keterkaitan antara kedua variabel tersebut, ditambah dengan pandangan penulis guna memperkuat keterkaitan data-data tersebut.

\section{HASIL DAN PEMBAHASAN Penguatan Kapasitas}

Dalam KBBI Online (kbbi.we.id/kuat), penguatan memiliki makna yang sama dengan proses, cara, perbuatan menguati atau menguatkan. Secara psikologis, penguatan adalah respons terhadap suatu perilaku yang dapat meningkatkan kemungkinan berulangnya kembali perilaku tersebut. Dalam ilmu administrasi, penguatan memiliki makna yang setara dengan pengembangan, sehingga jika dikaitkan dengan kapasitas muncul istilah pengembangan kapasitas.

Secara teknis upaya pengembangan merupakan konsekuensi logis dari suatu kondisi yang kurang baik. Dalam hal pemerintahan, sudah lama dikenal istilah good governance yang secara ringkas bertujuan untuk meningkatkan pelayanan publik, namun faktanya sampai saat ini citacita tersebut belum tercapai secara maksimal. Peningkatan tentu ada, tetapi harus jujur diakui bahwa masih banyak aspek yang perlu diperbaiki dan ditingkatkan. Apalagi jika dikaitkan dengan fenomena perubahan zaman yang terus berlangsung, di mana sistem pelayanan publik harus berusaha menyesuaikan diri dengan tuntutan perubahan tersebut, salah satunya fenomena revolusi industri 4.0 yang menuntut aparatur negara, termasuk yang bergerak di bidang administrasi untuk mampu beradaptasi dan menyelaraskan diri dengan situasi yang ada. Maka, untuk mengantisipasi sekaligus menghadapi permasalahan tersebut, diperlukan upaya pengembangan kapasitas organisasi untuk pemerintah daerah. (Alam dan Prawito, 2015). Kapasitas organisasi dapat diartikan sebagai kemampuan, keterampilan, pemahaman, sikap, nilai-nilai, hubungan, perilaku, motivasi, sumber daya, 
dan kondisi-kondisi yang memungkinkan setiap individu, organisasi, jaringan kerja, sektor, untuk melaksanakan fungsi masingmasing dalam mencapai tujuan pembangunan yang telah ditetapkan dari waktu ke waktu. (Milen,2006), Pengembangan kapasitas SDM mengacu kepada proses dimana individu, kelompok, organisasi, kelem-bagaan, dan masyarakat mengembangkan kemampuannya baik secara individual maupun kolektif untuk melaksanakan tugas dan fungsi SDM dalam menyelesaikan masalah yang berkaitan dengan bidang tugas yang menjadi tanggungjawabnya.

UNDP menjelaskan lebih lanjut, bahwa pada intinya pengembangan kapasitas bertujuan untuk meningkatkan kemampuan SDM dalam hal : a) Menghasilkan kinerja pelaksanaan tugas pokok dan fungsi (core functions), memecahkan permasalahan, merumuskan dan mewujudkan pencapaian tujuan yang telah ditetapkan; dan b) Memahami dan memenuhi kebutuhan pembangunan dalam konteks yang lebih luas dalam cara berkelanjutan. (UNDP,1999). Pengembangan kapasitas organisasi menyangkut berbagai dimensi, salah satunya adalah dimensi Sumber Daya Manusia (SDM), difokuskan kepada personel yang profesional dan kemampuan teknis serta tipe kegiatan seperti: training, praktek langsung, kondisi iklim kerja, dan rekrutmen. Dengan demikian, dalam konteks pengembangan kapasitas SDM, perhatian manajer difokuskan kepada pengadaan atau penyediaan personel yang profesional dan teknis. Adapun kegiatan yang relevan dengan hal itu adalah pendidikan dan latihan (training), pemberian gaji/upah yang layak (kompensasi), pengaturan kondisi dan lingkungan kerja serta penerapan sistem rekrutmen yang tepat.

Berdasarkan hasil studi Grindle dan Hilder-Brand di beberapa negara berkembang (Grindle,1997), terdapat lima dimensi utama yang menjadi sasaran pengembangan kapasitas, satu diantaranya adalah Human Resources Dimension (HRD), difokuskan tentang bagaimana SDM dididik dan ditarik untuk berkarir di sektor publik dan pemanfaatan serta penempatan individu ketika mereka mengejar karir seperti ini. Secara lebih spesifik, pengembangan kapasitas diarahkan pada kemampuan manajerial, profesional, dan teknis serta sejauh mana pelatihan dan jenjang karir dapat mempengaruhi kinerja keseluruhan pada setiap tugas yang diberikan kepadanya.

Pengembangan kapasitas SDM secara individu, merupakan bagian strategis dan mendasari dimensi lainnya. Oleh karena itu, Leavit dalam Djatmiko (2004) menempatkan pengembangan kapasitas SDM pada tingkat pertama, yakni : 1) Tingkat individu; 2) Tingkat kelembagaan; dan 3) Tingkat Sistem. Lebih jelasnya, disajikan pada gambar $1 \mathrm{di}$ bawah ini.

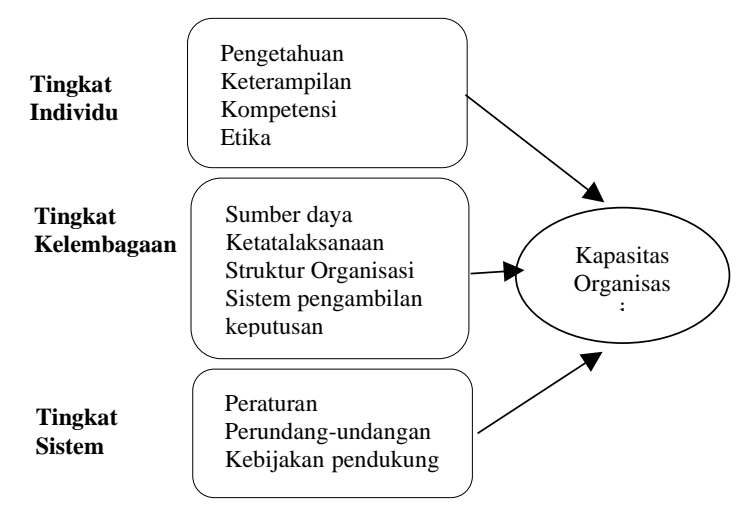

Gambar 1. Tingkat Penguatan Kapasitas.

Sumber : Leavit dalam Djatmiko (2004)

Merujuk pada tingkat pengembangan kapasitas menurut Leavit tersebut, program pengembangan kapasitas SDM perlu dirancang dengan menerapkan suatu metode yang sekiranya dapat mengubah pengetahuan, keterampilan, keahlian, sikap dan perilaku SDM. Dengan demikian, perlu diusahakan agar pengembangan kapasitas SDM secara individu dapat berdampak positif pada penguatan kapasitas, penguatan kelembagaan, dan penguatan sistem.

Dalam pembahasan ini, kapasitas sumber daya manusia merupakan kemampuan SDM secara individu yang bekerja dalam suatu lembaga atau instansi pemerintah daerah dalam menjalankan tugas dan fungsi serta kewenangan yang dimilikinya dalam upaya mencapai tujuan secara efektif dan efisien. Kapasitas tersebut dilihat dari aspek pengetahuan, keterampilan, kompetensi, dan untuk mencapai kinerja yang diharapkan.

Pentingnya pengetahuan bagi seorang pegawai, baik di lingkungan organisasi pemerintah maupun swasta tak diragukan lagi peran dan fungsinya. Tanpa memiliki 
pengetahuan, seorang pegawai mustahil dapat bekerja dengan baik. Tetapi tentu tidak sesederhana itu, pengetahuan yang dimaksud di sini adalah pengetahuan baru tertkait dengan kondisi yang sedang berkembang, terutama pengetahuan tentang revolusi industri 4.0 beserta dampak yang ditimbulkannya. Selain itu, pengetahuan merupakan aspek pertama dari kapasitas seorang pegawai yang terkait erat dengan kompetensi kerja. Dengan kata lain, pengetahuan yang perlu ditingkatkan bukan pengetahuan umum melainkan pengetahuan yang berkaitan dengan tugas yang diemban agar mampu melaksanakan pekerjaan dengan baik. Dalam hal ini Gibson (2008:56) mengemukakan bahwa pengetahuan merupakan tingkat pemahaman seseorang pegawai tentang apa yang dia ketahui dari pengalaman dan belajar. Pengetahuan seorang pegawai yang baik tentang bidang tugas yang menjadi tanggungjawabnya cenderung akan meningkatkan kualitas pekerjaannya.

Pentingnya keterampilan bagi seorang pegawai, erat kaitannya dengan lancarnya pelaksanaan kerja. Jika dikaitkan dengan kapasitas SDM, maka keterampilan merupakan aspek kedua dari kapasitas SDM secara individual. Keterampilan erat kaitannya dengan kemampuan motorik yang erat kaitannya dengan kecakapan kerja sesuai tugas yang dipergunakan oleh individu. (Gibson, 2008). Bagi SDM bidang administrtasi yang bertugas memberikan pelayanan kepada masyarakat (publik) harus berperilaku professional yang ditunjukkan melalui paduan pengetahuan dan keterampilan memiliki serta menerapkan teknologi yang relevan, juga memiliki dan menerapkan keterampilan kerja secara profesional. (Mathis and Jackson, 2002). Pandangan lain tentang pentingnya keterampilan dalam penguatan kapasitas SDM dikemukakan Notoatmodjo (2003:14), bahwa "Semakin tinggi keterampilan yang dimiliki oleh tenaga kerja, semakin efisien badan, tenaga, dan pemikirannya dalam melaksanakan pekerjaan". Teori tersebut diperkuat oleh hasil penelitian Sirait (2006:27), yang menunjukkan bahwa pendidikan dan pelatihan terbukti memberikan peningkatan keterampilan kepada pegawai yang dibutuhkan. Selain itu, menunjukkan bahwa dengan bertambahnya keterampilan kerja dapat meningkatkan rasa percaya diri pegawai dalam melaksanakan pekerjaannya.

Pentingnya kompetensi bagi SDM bidang administrasi, erat kaitannya dengan kualitas dan keabsahan hasil kerja. Dalam manajemen SDM, aspek kompetensi berhubungan erat dengan kinerja seorang pegawai. Secara logika mudah dipahami, bahwa kompetensi memang memiliki hubungan kausalitas dengan kinerja. Secara teoretis, terdapat klasifikasi kompetensi, salah satunya dikemukakan Talim (2003:7) yang menyatakan bahwa "Kompetensi dapat meliputi aspek pengetahuan, keterampilan, sikap dan perilaku". Tentang bagaimana suatu kompetensi dapat diperoleh, Dharma (2002:38) berpendapat bahwa kompetensi dapat diperoleh melalui berbagai cara, salah satunya adalah melalui umpan balik (feedback). Diyakini bahwa suatu pelatihan dimana seorang pegawai dapat mempraktekkan kompetensi yang dimiliki dan memperoleh umpan balik bagaimana pegawai dapat melaksanakan pekerjaan tertentu dibanding dengan seseorang yang berkinerja tinggi. Penguatan kapasitas SDM melalui pendidikan dan pelatihan dilakukan sebagai jawaban atas tuntutan perubahan lingkungan yang terus terjadi, salah satunya oleh revolusi industri 4.0 dengan munculnya sistem teknologi digital. Revolusi industri 4.0 tersebut berpengaruh terhadap pekerjaan, pekerja, dan tempat kerja.

Bagi pegawai bidang administrasi, agar dapat memperoleh dan memperkuat kompetensinya dapat dilakukan dengan metode pendidikan dan pelatihan. Smith (2000:2) mengemukakan "Pelatihan adalah proses terencana untuk mengubah sikap atau prilaku, pengetahuan dan keterampilan melalui pengalaman belajar untuk mencapai kinerja yang efektif dalam sebuah kegiatan atau sejumlah kegiatan". Hal serupa dikemukakan oleh Simanjuntak (1985:58) bahwa pelatihan dimaksudkan untuk meningkatkan keterampilan pegawai baik secara horizontal maupun vertikal. Intinya, program penguatan atau pengembangan kapasitas SDM dapat dilakukan melalui pendidikan dan pelatihan yang merupakan proses operasional logis. 
Berkenaan dengan suatu proses pengembangan kapasitas SDM melalui pendidikan dan pelatihan, secara teknis dapat merujuk kepada UNDP (1999), yang diilustrasikan dengan gambar sebagai berikut:

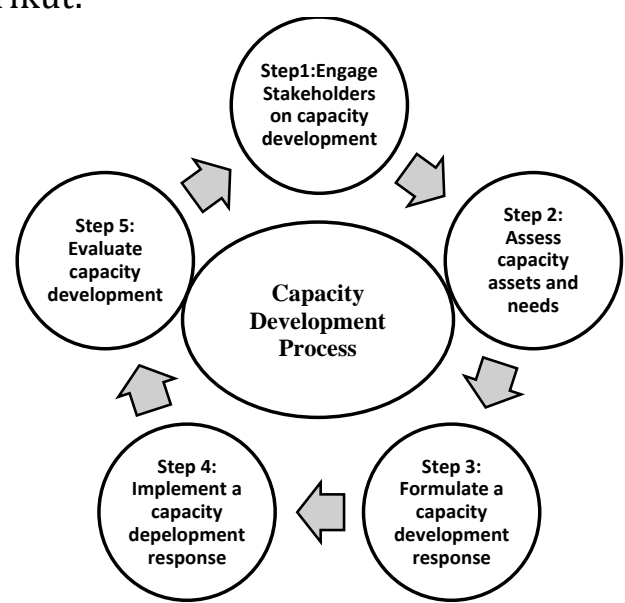

Gambar 2: Capacity Development Prosess Sumber : UNDP, 1999

Dari gamar 2 dapat diambil intisari bahwa proses pengembangan kapasitas SDM harus menempuh lima tahapan, yaitu : 1) Mengikutsertakan stakeholders dalam pengembangan kapasitas; 2) Menilai atau menganalisis kapasitas dan kebutuhan; 3) Merumuskan respon pengembangan kapasitas; 4) Menerapkan respon pengembangan kapasitas, dan 5) Evaluasi pengembangan kapasitas.

Dilihat dari segi aspek kapasitas SDM, agar tujuan pengembangan tercapai secara efektif dan efisien, maka proses yang ditempuh perlu memperhatikan aspek-aspek penting, yaitu : 1) Performance capacity; 2) Personal capacity; 3) Workload capacity; 4) Supervisory capacity; 5) Facility capacity; 6) Support service capacity; 7) Systems capacity; 8) Structural capacity; dan 9) Role capacity (Potter \& Brough, 2004:341). Dengan demikian, gagasan pengembangan SDM bertujuan untuk meningkatkan kapasitas individu dalam menjalankan tanggung jawabnya secara professional dan meningkatkan kemampuan teknisnya (Haryono, 2012). Teknis yang dimaksud adalah teknis pelaksanaan kerja dalam rangka memberikan pelayanan kepada publik.

Menurut KBBI (1990) "Pelayanan adalah perihal atau cara melayani" sedangkan "Publik berarti orang banyak (umum)".
Berkenaan dengan pelayanan publik Moenir (1995:7) mengemukakan bahwa "Pelayanan umum adalah suatu usaha yang dilakukan kelompok atau seseorang atau birokrasi untuk memberikan bantuan kepada masyarakat dalam rangka mencapai suatu tujuan tertentu". Pendapat senada dikemukakan Sinambela (2006:5) yang menyatakan bahwa "Pelayanan publik adalah pemenuhan keinginan dan kebutuhan masyarakat oleh penyelenggara negara". Dalam UU Nomor 25 tahun 2009 tentang Pelayanan Publik, pada Pasal 8 dikemukakan bahwa "Penyelenggara dan seluruh bagian organisasi penyelenggara bertanggung jawab atas ketidakmampuan, pelanggaran, dan kegagalan penyelenggaraan pelayanan", sehingga sikap dan perilaku yang beretika aparat menjadi penting. Pada Pasal 34, dijelaskan bahwa pelaksana dalam menyelenggarakan pelayanan publik harus berperilaku : Adil dan tidak diskriminatif; Cermat; Santun dan ramah, Tegas, andal, dan tidak memberikan putusan yang berlarutlarut; Profesional; Tidak mempersulit; Patuh pada perintah atasan yang sah dan wajar; Menjunjung tinggi nilai-nilai akuntabilitas dan integritas institusi penyelenggara; Tidak membocorkan informasi atau dokumen yang wajib dirahaslakan sesuai dengan peraturan perundang-undangan; Terbuka dan mengambil langkah yang tepat untuk menghindari benturan kepentingan; Tidak menyalahgunakan sarana dan prasarana serta fasilitas pelayanan publik; Tidak memberikan informasi yang salah atau menyesatkan dalam menanggapi permintaan informasi serta proaktif dalam memenuhi kepentingan masyarakat; Tidak menyalahgunakan informasi, jabatan, dan/atau kewelangan yang dimiliki; Sesuai dengan kepantasan; dan Tidak menyimpang dari prosedur.

Untuk Memenuhi tuntutan tersebut diperlukan SDM yang memiliki kapasitas tinggi secara individual agar dapat menjadi pegawai professional dan menyenangkan, sehingga masyarakat yang dilayani merasa puas.

\section{Pembahasan}

Dengan memperhatikan intisari dari teri-teori tentang pengembangan kapasitas SDM secara individual baik berkenaan 
dengan hierarchy tingkat pengembangan, proses pengembangan, dan aspek-aspek pengembangan kapasitas SDM, tujuannnya adalah untuk meningkatkan pengetahuan, keterampilan, dan kompetensi pegawai agar mampu beradaptasi dengan perubahan zaman yang sedang barlangsung serta siap memberikan pelayanan kepada publik secara professional.

Kapasitas dan kualitas SDM secara individu tidak sekedar ditentukan oleh pengetahuan dan keterampilan dalam melaksanakan tugas, melainkan terdapat faktor lain yang mempengaruhinya. Salah satu faktor dimaksud adalah ditentukan oleh perilaku dan etika kerja. Hal tersebut senada dengan pandangan Frenc dan Bell (Indrawijaya, 1983), bahwa pimpinan memiliki penting dalam menciptakan iklim kerja yang kondusif melalui keteladanan yang baik. Dampaknya, setiap individu pegawai terdorong untuk menjunjung tinggi nilai-nilai etika dalam melaksanakan tugas. bekerja. Dengan demikian, penguatan kapasitas SDM secara individu, diperlukan juga tentang pentingnya penanaman etika kerja.

Dalam pelaksanaan kerja untuk menunaikan tugas dan kewajiban seorang pegawai, pengetahuan, keterampilan, kompetensi dan etika yang dimiliki individu akan terintegrasi dalam kepribadian individu serta tercermin dalam perilaku secara utuh ketika sedang bekerja melayani publik.

Untuk dapat mencapai kepribadian yang utuh dengan tampilan kerja yang professional, ketika pegawai dilibatkan dalam proses pendidikan dan pelatihan untuk mengembangkan kapasitas dirinya, diperlukan penguatan terhadap aspek-aspek kapasitas secara menyeluruh, yaitu sebagai berikut:

Pertama, Performance capacity menyangkut ketersediaan alat atau bendabenda yang berfungsi sebagai pendukung suatu kinerja. Misalnya uang, peralatan kerja, bahan habis pakai, penerangan, listrik dan sebagainya. Untuk memastikan bahwa individu memiliki kapasitas yang memadai perlu didukung performance capacity.

Kedua, Personal capacity penting untuk diperhatikan dan dipertimbangkan untuk dijadikan dasar penyusunan program pengembangan kapasitas SDM. Hal ini penting, terutama harus dianalisis sebelum program pendidikan dan pelatihan dilaksanakan. Hal-hal yang harus diketahui secara akurat antara lain kondisi individu, apakah telah memiliki pengetahuan, keterampjilan, dan kepercayaan diri untuk melakukan suatu pekerjaan dengan benar? Jika telah diketahui, lakukan analisa lebih mendalam apakah individu tersebut membutuhkan pelatihan, pengalaman baru, atau sekedar membutuhkan motivasi. Selain itu, kaitkan dengan peran individu pada saat bekerja dengan tim serta keterkaitannya dengan proses kerja managerial secara keseluruhan. Apakah kompetensinya cukup baik atau kurang?

Ketiga, Workload capacity erat kaitannya dengan beban kerja individu. Hal yang perlu dipertimbangkan adalah berkenaan dengan kemampuan individu, apakah cukup memadai untuk mengatasi beban kerja yang dibebankan kepadanya? Selain itu, butuh kepastian apakah deskripsi pekerjaan yang diberikan dapat dilakukan dengan baik atau bersifat spekulatif? Dengan demikian, dalam upaya mengembangkan kapasitas SDM secara individu, kondisi beban kerja perlu diperhatikan dengan seksama.

Keempat, Supervisory capacity yang berkaitan erat dengan pengawasan. Artinya, kapasitas SDM secara individu tidak akan maksimal memberikan dampak pada pencapaian tujuan organisasi jika tidak diimbangi dengan kapasitas pengawasan. Bentuk pengawasan bermacam-macam, baik langsung maupun tidak langsung. Secara spesifik, perlu diperhatikan apakah terdapat laporan dan sistem monitoring di tempat kerja? Bagaimana keberadaan pengawas fisik yang dapat memantau pegawai saat bekerja? Selain itu, apakah tersedia dengan jelas tentang insentif yang efektif bagi yang berprestasi dan sanksi yang tegas bagi yang malas? Kondisi tersebut diduga akan berpengaruh terhadap kapasitas SDM secara individu, maka penting untuk diperhatikan.

Kelima, Facility capacity berkaitan erat dengan fasilitas yang tersedia di tempat pendidikan dan pelatihan. Fasilitas dimaksud menyangkut sarana prasarana dan ketersediaan personal pelaksana Diklat, baik secara kuantitatif maupun kualitatif. Selain itu, perlu juga dipertimbangkan dan diperhitungkan secara matang tentang rasio nara sumber dengan jumlah peserta diklat. 
Keenam, Support service capacity berkaitan dengan ketersediaan faktor-faktor pendukung pelaksanaan pendidikan dan pelatihan. Faktor pendukung terdiri atas beberapa macam dengan karakter berbeda yang erat kaitannya dengan pelaksanaan diklat. Antara lain berupa laboratorium yang relevan, lembaga pelatihan yang handal, staf administrasi yang profesional, binatu yang jujur, penyedia layanan konsumsi yang solid, fasilitas penelitian, layanan kontrol kualitas, dan yang lainnya. Semua itu dapat diperoleh melalui kerjasama dengan pihak swasta, tetapi mereka wajib taat terhadap aturan yang berlaku.

Ketujuh, Systems capacity yang erat kaitannya dengan sistem kesatuan kerja yang terdiri atas beberapa komponen atau unsur yang berbeda-beda tetapi mendukung tujuan yang sama. Komponen-komponen tersebut antara lain lalu-lintas informasi, arus keluarmasuk uang (biaya), proses manajerial berkaitan dengan pengambilan keputusaan (apakah efektif atau tidak), kerjasama dengan pihak swasta, komunikasi dengan masyarakat, atau koordinasi dengan pihak LSM yang relevan. Harmonisasi dari semua komponen tersebut diperlukan agar pelaksanaan pendidikan dan pelatihan berjalan efektif dan efisien serta sukses mencapai tujuan yang diharapkan.

Kedelapan, Structural capacity yang berkaitan dengan keberadaan suatu forum di mana di dalamnya dapat terjadi diskusi lintas sektoral untuk mengambil keputusan yang tepat dan akurat.

Kesembilan, Role capacity erat kaitannya dengan peran seseorang atau individu dalam organisasi. Untuk suksesnya program pendidikan dan pelatihan, peran individu tersebut tentu berkaitan dengan tim kerja dalam organisasi pelaksana Diklat. Di luar itu, peran individu dalam dunia kerja masing-masing juga perlu diperhatikan, karena dalam pelaksanaan kerja terkait dengan pelayanan publik peran individu sangat berpengaruh terhadap kualitas pelayanan publik. Hal yang lebih spesifik dari role capacity adalah pentingnya memperhatikan kejelasan kewenangan masing-masing karena ada kaitannya dengan proses pengambilan keputusan. Kemudian tentang keakuratan jadwal dan kejelasan pendukung kerja berupa sarana dan biaya.

\section{PENUTUP}

Memperhatikan perkembangan ilmu pengetahuan dan teknologi serta mewaspadai perubahan social yang terus terjadi merupakan salah satu sikap visioner dari para pemangku kebijakan, para manajar, atau para pemimpin organisasi termasuk di lingkungan organisasi pemerintah. Proses berkembangnya wacana revolusi industri 4.0 yang akan berdampak kepada dunia kerja, pekerja, dan pekerjaan sudah selayaknya mendapat perhatian serius dari para pengelola dan pembina sumber daya manusia agar SDM yang dimiliki tidak tergilas arus perubahan yang terus terjadi.

Berkenaan dengan kondisi demikian, setiap pemimpin instansi atau organisasi perlu mengambil langkah konkret untuk mempersiapkan SDM yang memiliki pengetahuan, keterampilan, kompetensi dan sikap etis yang memadai guna menghadapi dampak kemajuan teknologi agar tetap dapat memberikan pelayanan public secara professional. Salah satu cara yang dapat ditempuh lembaga guna mempersiapkan SDM tersebut adalah melalui pelaksanaan pendidikan dan pelatihan yang terencana dengan baik untuk memperkuat kapasitas SDM. Pendidikan dan pelatihan yang baik perlu mempertimbangkan tingkat kapasitas, difokuskan pada tingkat pertama yaitu kapasitas individu, dengan sasaran utama untuk mengembangkan pengetahuan, keterampilan, kompetensi, dan etika. Selain itu, memperhatikan proses pengembangan kapasitas yang meliputi lima tahapan, yaitu: Step 1, Engage Stakeholders on capacity development; Step 2, Assess capacity asset; Step 3, Formulate a capacity development; Step 4, Implement a capacity development response; dan Step 5, Evaluate capacity development. Dalam pelaksanaan pendidikan dan pelatihan, perlu memperhatikan sembilan aspek pengembangan kapasitas, yaitu: Performance capacity; Personal capacity; Workload capacity; Supervisory capacity; Facility capacity; Support service capacity; Systemscapacity; Structural capacity; dan Role capacity. Dengan demikian, kapasitas SDM secara individual setelah mengikuti pendidikan dan pelatihan akan semakin kuat sehingga pada gilirannya dapat bekerja secara profesional dan memberikan pelayanan yang baik kepada publik. 


\section{DAFTAR PUSTAKA}

Alam, Andi Samsu dan Prawitno, Ashar (2015). Pengembangan Kapasitas Organisasi dalam Peningkatan Kualitas Pelayanan Publik Dinas ehutanan dan Perkebunan Kabupaten Bone, Jurnal Ilmu Pemerintahan, 8(2).93-104.

Basnawi, Choiriyah (2017). Pengembangan Kapasitas Sumber Daya Manusia Dalam Pengelolaan Keuangan Daerah Melalui Clinic Center Oleh Unit Pelaksana Teknis laboratorium Pengelolaan Keuangan Daerah (UPTLPKD) Jawa Timur, Jurnal Kebijakan dan Manajemen Publik, 5(3), 1-9.

Djatmiko, Y. (2004). Perilaku Organisasi. Bandung: CV. Alfabeta.

Gibson, M. 2008. Manajemen Sumber Daya Manusia. Cetakan ke dua. Jakarta: Erlangga.

Grindle, M. (1997). Getting Good Government: Capacity Building The Public Sector of Developing Countries. Boston: Harvard Institute for International Development.

Hamdan. (2018). Industri 4.0: Pengaruh Revolusi Industri Pada Kewirausahaan Demi Kemandirian Ekonomi, Jurnal Nusamba, 3(2), 1-8.

Haryono, Adipurnomo, (2012). Strategi Intervensi dalam Implementasi Nilainilai Pendidikan Karakter Bangsa di Sekolah. [Online]. Diakses dari http://haryonoadipurnomo.wordpress .com/2012/01/11/strategi-intervensi nilai-nilai pendidikan karakterbangsa di sekolah.

Indrawijaya, A. (1983). Perubahan dan Pengembangan Organisasi. Bandung: Sinar Baru.

Kamariah, (2012). Capacity Building Birokrasi Pemerintah Daerah Kabupaten/Kota di Indonesia, Makassar:-tp-

Kagermann, H., Lukas, W.D., \& Wahlster, W. (2013). Final report: Recommendations for implementing the strategic initiative INDUSTRIE 4.0. Industrie 4.0 Working Group.

Mathis Robert, Jackson John. (2002). Manajemen Sumber Daya Manusia. Jakarta : Salemba Empat
Muhammad Hamka Amin, Herman Sjahruddin, Syamsul Alam, dan Syahruni (2016). Kapasitas Sumber Daya Manusia dan Pemanfaatan Teknologi Informasi Konsekuensinya pada Kinerja Karyawan, Jurnal ELibrary STIE YPBUP 2(35),35-48.

Milen, A. (2006). What Do We Know About Capacity Building?, An Overview of Existing Knowledge and Good Practice, World Health Organization. Geneva: Departement of Health Service Provision.

Nasution, Erla. (2011). Analisis Kapasitas Individu, Partisipasi Penganggaran, Komitmen Organisasi, dan Kesenjangan Anggaran Pada Satuan Perangkat Kerja Daerah Kabupaten Langkat. Tesis. Universitas Sumatera Utara.

Notoatmodjo, Soekidjo. (2003). Pendidikan Dan Perilaku Kesehatan. Jakarta: Rineka Cipta.

Pannen, Paulina (2018). Mempersiapkan SDM Indonesia di Era Industri 4.0, Jakarta: Ristekdikti.

Pratama, M. Hamdani. (2015) Strategi Meningkatkan Kualitas Pelayanan Publik, Jurnal Kebijakan dan Manajemen Publik, 3 (3), 90-98.

Prasetyo, Hoedi dan Sutopo Wahyudi (2018). Industri 4.0: Telaah klasifikasi Aspek dan Arah Perkembangan Riset, Jurnal Teknik Industri, 13(1), 17-26.

Potter, C., \& Brough, R. (2004). Systemic capacity building: a hierarchy of needs. Health policy and planning, 19(5), 336345.

Rinaldi, Rudi.; (2012) Analisis Kualitas Pelayanan Publik (Studi Pada Biro Umum Sekretariat Daerah Propinsi Sumatera Utara), Jurnal Administrasi, 1 (1), 22-34.

Rohida, Leni. (2018) Pengaruh Era Revolusi Industri 4.0 terhadap Kompetensi Sumber Daya Manusia, 6 (1), 114-136.

Simangunsong, Benedictus Arnold. (2011). Evolusi Saluran Interaksi di Era Internet. Jurnal Komunikasi. 1(3).

Simanjuntak, Payaman. (1985). Pengantar Ekonomi Sumber Daya Manusia, Jakarta: FE UI.

Sinambela, Lijan Poltak, (2006). Reformasi Pelayanan Publik : Teori, Kebijakan dan Implementasi, Jakarta: Bumi Aksara. 
Sirait, Justin.T. (2006). Memahami Aspekaspek Pengelolaan Sumber Daya Manusia dalam. Organisasi. Jakarta: Gramedia Widiasarana Indonesia.

Sonia, Dewi Puspita (2016) Pengaruh Kapasitas Sumber Daya Manusia, Pemanfaatan Teknologi Informasi, Sistem Pengendalian Intern Pemerintah Terhadap Nilai Informasi Pelaporan Keuangan Pemerintah Daerah, Jurnal JOM Fekon, 3(1), 21042118.

Sutrisno, Edy. (2010). Manajemen Sumber Daya Manusia. Jakarta: Kencana.

Sugiyono (1998), Metode Penelitian Administrasi, Bandung: Alfabeta.

Surya Dharma, (2002), Paradigma Baru Manajemen Sumber Daya Manusia, Yogyakarta: Amara Books.

Smith, C.A.Organ, D.W. \& Near, J.P. (2002). Organization Citizenship Behavior. Its Nature and Antecendent. Journal of Applied Psychology, 68,4,653-663.

Schwab, Klaus, "The Global Competitiveness Report 2017-2018".World Economic Forum Insight Report, ISBN-13: 978-1944835-11-8.

Smith, N dan Ainsworth. (2002). Managing Performance Managing People: Panduan Praktis untuk memahami dan Meningkatkan Performa Tim, Jakarta: PT. Bhuan Ilmu Populer.

Talim, Banowati. (2003). Solusi Proaktif Permasalahan SDM di Indonesia. Pikiran Rakyat, halaman 11.

Undang-Undang Republik Indonesia Nomor 25 Tahun 2009 Tentang Pelayanan Publik.

UNDP. (1999). Peningkatan Kinerja Pembangunan Daerah. Jakarta: UNDP Indonesia

\section{BIOGRAFI PENULIS}

\begin{tabular}{|l|l|}
\hline & Dr.H. Lalan Soeherlan S, Drs. M.Si, Lektor, menjabat sebagai Wakil Direktur I bidang \\
Akademik dan Kemahasiswaan pada Program Pascasarjana Universitas \\
Majalengka. Mengampu mata kuliah Keuangan Negara dan Daerah, Teori dan Isu \\
Pembangunan, Konsep dan Teori Administrasi. \\
Email: lalansoeherlans@gmail.com
\end{tabular}

